\title{
Modeling of Texture Evolution during Hot Forging of Alpha/Beta Titanium Alloys
}

\author{
M.G. GLAVICIC, R.L. GOETZ, D.R. BARKER, G. SHEN, D. FURRER,
}

A. WOODFIELD, and S.L. SEMIATIN

DOI: $10.1007 / \mathrm{s} 11661-008-9559-5$

(C) The Minerals, Metals \& Materials Society and ASM International 2008

\section{Erratum to: METALLURGICAL AND MATERIALS \\ TRANSACTIONS A, Vol. 39A, No. 4, April 2008 \\ DOI: $10.1007 / \mathrm{s} 11661-007-9376-2$}

THE year of publication is misprinted as 2007 in the running feet of the original article. This article appears in the April 2008 issue.

M.G. GLAVICIC, Research Scientist, R.L. GOETZ, Research Engineer, and D.R. BARKER, Project Manager, are with UES, Inc., Dayton, OH 45432, USA. Contact e-mail: michael.glavicic@ wpafb.af.mil G. SHEN, Research Engineer, and D. FURRER, Research Scientist, are with the Rolls-Royce Corporation, Indianapolis, IN 46206-0420, USA. A. WOODFIELD, Senior Scientist, is with General Electric Aviation, Cincinnati, OH 45215, USA. S.L. SEMIATIN, Senior Scientist, is with the Air Force Research Laboratory, Materials and Manufacturing Directorate, AFRL/MLLM, Wright-Patterson AFB, Dayton, OH 45433-7817, USA.

The online version of the original article can be found under doi: 10.1007/s11661-007-9376-2.

Article published online May 1, 2008 